\title{
Penegakan Hukum terhadap Tindak Pidana Tanpa Hak Menguasai Senjata Tajam dalam Aksi Unjuk Rasa Penolakan RUU KUHP
}

\section{Law Enforcement Against Criminal Actions Without The Right To Control Sharp Weapons In Responsibility to Reject The KUHP Rule}

\author{
Imanuel Sembiring1), Ediwarman2) \& Marlina2)
}

\author{
1)Program Studi Magister Ilmu Hukum, Universitas Medan Area, Indonesia \\ 2) Fakultas Hukum, Universitas Sumatera Utara, Indonesia \\ Diterima: 14 Juni 2021; Direview: 02 Agustus 2021; Disetujui: 04 Oktober 2021
}

*Coresponding Email: imanuel@gmail.com

\begin{abstract}
Abstrak
Tulisan ini bertujuan untuk mengkaji dan menganalisis aturan hukum, penegakan hukum dan kebijakan pidana terhadap tindak pidana tanpa hak menguasai senjata tajam. Guna mendekati masalah ini dipergunakan teori sistem hukum. Data-data dikumpulkan melalui pedoman wawancara dan dianalisis secara kualitatif. Kajian ini menyimpulkan bahwa aturan hukum mengenai penegakan hukum terhadap tindak pidana tanpa hak menguasai senjata tajam dalam aksi unjuk rasa diatur dalam Undang-Undang Darurat Nomor 12 Tahun 1951 pada Pasal 2 ayat (1), Undang-undang No. 9 Tahun 1998 tentang Kemerdekaan Menyampaikan Pendapat di Muka Umum pada Pasal 16, Perkapolri No. 7 tahun 2012 tentang Tata Cara Penyelenggaraan Pelayanan, Pengamanan, dan Penanganan Perkara Penyampaian Pendapat di Muka Umum pada Pasal 8 huruf j. Penegakan hukum terhadap tindak pidana tanpa hak menguasai senjata tajam dalam aksi unjuk rasa penolakan RUU KUHP di Pengadilan Negeri Medan dilakukan melalui penyidikan, penuntututan dan putusan hakim. Kebijakan hukum pidana terhadap orang yang membawa senjata tajam di Kota Medan terdiri dari kebijakan penal dilakukan dengan memproses pelaku secara hukum yang dilanjutkan dengan melakukan pemeriksaan terhadap terdakwa di persidangan. Kebijakan non penal sebagai tindakan pencegahan tindak pidana tanpa hak menguasai senjata tajam adalah penyuluhan, razia dan partisipasi masyarakat.
\end{abstract}

Kata Kunci: Penegakan Hukum; Tindak Pidana; Tanpa Hak Menguasai Senjata Tajam; Aksi Unjuk Rasa.

\begin{abstract}
This paper aims to examine and analyze the rule of law, law enforcement and criminal policy against criminal acts without the right to control sharp weapons. To approach this problem, the theory of the legal system is used. The data were collected through interview guidelines and analyzed qualitatively. This study concludes that the rule of law regarding law enforcement against criminal acts without the right to control sharp weapons in demonstrations is regulated in Emergency Law Number 12 of 1951 in Article 2 paragraph (1), Law no. 9 of 1998 concerning Freedom to Express Opinions in Public in Article 16, Perkapolri No. 7 of 2012 concerning Procedures for the Implementation of Services, Security, and Handling of Public Opinion Cases in Article 8 letter j. Law enforcement against criminal acts without the right to control sharp weapons in demonstrations against the Criminal Code Bill at the Medan District Court is carried out through investigations, prosecutions and judges' decisions. The criminal law policy against people who carry sharp weapons in Medan City consists of a penal policy carried out by legally processing the perpetrators, followed by examining the defendants at trial. Non-penal policies as a preventive measure for criminal acts without the right to control sharp weapons are counseling, raids and community participation.
\end{abstract}

Keywords: Law Enforcement; Crime; Without the Right to Control Sharp Weapons; Demonstrations

How to Cite: Sembiring, I., Ediwarman., \& Marlina. (2021). Penegakan Hukum terhadap Tindak Pidana Tanpa Hak Menguasai Senjata Tajam dalam Aksi Unjuk Rasa Penolakan Ruu Kuhp. Journal of Education, Humaniora and Social Sciences (JEHSS). 4(2): 1075-1080 


\section{PENDAHULUAN}

Maraknya tindak pidana terutama disebabkan keinginan-keinginan manusia yang tidak terbatas dan tidak dapat mengendalikan diri untuk menjalani kehidupan sesuai dengan normanorma yang wajar, sehingga terdapat dorongan yang kuat untuk memenuhi keinginan dengan menghalalkan berbagai cara, termasuk dengan melakukan tindak pidana.

Salah satu tindak pidana yang perlu mendapat perhatian adalah tindak pidana membawa senjata penikam, atau sering disingkat dengan senjata tajam (Koeswadji, 2013). Penguasan atau membawa senjata penikam pada tempat dan waktu yang tidak tepat sering menjadi pertanda bahwa akan terjadi tindak pidana lain yang akan dilakukan oleh pembawa, karena biasanya pada kondisi tersebut fungsi sejata tajam atau untuk mempertahankan diri atau untuk menyerang orang lain secara fisik (Muladi \& Nawawi, 2012). Disamping itu, penguasaan benda penusuk dapat mendorong niat seseorang untuk menggunakannya menyerang orang lain, sehingga penguasaan atau membawa senjata penusuk digolongkan sebagai tindak kriminal.

Pelarangan dalam penguasaan senjata penikam telah menjadi masalah klasik yang sudah sangat lama diterapkan mengingat bahaya yang dapat ditimbulkan dari sejata penikam atau sejenisnya yang dapat mendorong niat atau keinginan seseorang untuk melakukan tindak pidana lain seperti tindak pidana kekerasan terhadap orang lain. Terdapat banyak tindak kriminal dalam bentuk kekerasan dengan menggunakan senjata penikam, baik untuk mempertahankan diri ataupun untuk menyerang orang lain, dimana niat jahat tersebut akan mudah timbul jika terdapat senjata penikam yang melekat di badan seseorang (Rahardjo, 2015).

Pelarangan terhadap senjata penikam di atur dalam UU Darurat No. 12 Tahun 1951. Pada pasal 2 ayat (1) dinyatakan: "Barang siapa yang tanpa hak memasukkan ke Indonesia, membuat, menerima, mencoba memperolehnya, menyerahkan atau mencoba menyerahkan, menguasai, membawa, mempunyai persediaan padanya atau mempunyai dalam miliknya, menyimpan, mengangkut, menyembunyikan, mempergunakan atau mengeluarkan dari Indonesia sesuatu senjata pemukul, senjata penikam, atau senjata penusuk (slag-, steek-, of stootwapen), dihukum dengan hukuman penjara setinggi-tingginya sepuluh tahun".

Salah satu kasus senjata tajam di dalam unjuk rasa dilakukan oleh terdakwa Ruslan Abdul Gani. Secara kronologis, terdakwa bersama rekan-rekannya lari ke arah lapangan merdeka dengan tujuan untuk bergabung melakukan unjuk rasa yang saat itu sedang terjadi di Kantor DPRD Medan. Kemudian saksi yang merupakan petugas kepolisian melakukan pemeriksaan terhadap dan menemukan sebilah pisau berwarna coklat emas dari dalam tas yang digunakan oleh terdakwa. Terdakwa tidak memiliki izin atas penguasaan senjata tajam tersebut sehingga saksi membawa terdakwa berserta barang bukti ke Kantor Polsek Medan Timur.

\section{METODE PENELITIAN}

Spesifikasi penelitian yang dipergunakan dalam penelitian ini adalah metode penelitian yuridis normatif bersifat deskriptif analisis, yaitu penelitian yang dilakukan dengan cara meneliti bahan pustaka (data sekunder) atau penelitian hukum perpustakaan (Soekanto, 2012). Penelitian hukum normatif merupakan suatu prosedur penelitian ilmiah untuk menemukan kebenaran berdasarkan logika keilmuan hukum dari sisi normatifnya. Penelitian hukum normatif atau doktriner yang diajukan dalam kajian ini adalah penelitian terhadap asas-asas hukum dan sinkronisasi hukum.

Penelitian ini menggunakan bahan yang diperoleh dari hasil penelitian kepustakaan, dari penelitian kepustakaan dikumpulkan data sekunder yang meliputi bahan hukum primer, bahan hukum sekunder dan bahan hukum tersier (Ediwarman, 2016). Penelitian normatif, data yang diperlukan adalah data sekunder. Data sekunder tersebut mempunyai ruang lingkup yang sangat luas, sehingga meliputi surat-surat pribadi, buku-buku harian, sampai pada dokumen-dokumen resmi yang dikeluarkan oleh pemertintah (Abdulkadir, 2014).

Alat pengumpulan data menggunakan studi dokumen dan pedoman wawancara. Data yang diperoleh melalui penelitian kepustakaan maupun data yang diperoleh melalui penelitian lapangan akan dianalisis secara kualitatif. Analisis kualitatif yaitu analisis data dengan mengelompokkan dan menyelidiki data yang diperoleh dari penelitian lapangan menurut kualitas 10.746 http://mahesainstitute.web.id/ojs2/index.php/jehss 1076 
kebenarannya, kemudian dihubungkan dengan teori-teori yang diperoleh dari studi kepustakaan, sehingga diperoleh jawaban dari permasalahan yang diajukan (Moloeng, 2015).

\section{HASIL DAN PEMBAHASAN}

\section{Aturan hukum mengenai penegakan hukum terhadap tindak pidana tanpa hak menguasai} senjata tajam dalam aksi unjuk rasa

Berdasarkan Undang-undang (Drt) No. 12 Tahun 1951: Yang dimaksud senjata tajam adalah senjata penikam, senjata penusuk, dan senjata pemukul tidak termasuk barang-barang yang nyatanyata dimasukkan untuk dipergunakan guna pertanian, atau untuk pekerjaan-pekerjaan rumah tangga atau untuk kepentingan melakukan dengan sah pekerjaan atau yang nyata-nyata mempunyai tujuan sebagai barang pusaka atau barang kuno atau barang ajaib (merkwaardigheid).

Kepemilikan senjata tajam yang tidak digunakan untuk keperluan rumah tangga dan alat pertanian merupakan suatu kejahatan. Dalam Pasal 2 ayat (1) Undang-Undang ini juga disebutkan bahwa "Barang siapa yang tanpa hak memasukkan ke Indonesia, membuat, menerima, mencoba memperolehnya, menyerahkan atau mencoba menyerahkan, menguasai, membawa, mempunyai persediaan padanya atau mempunyai dalam miliknya, menyimpan, mengangkut, menyembunyikan, mempergunakan atau mengeluarkan dari Indonesia suatu senjata pemukul, senjata penikam, atau senjata penusuk (slag, steek of stoot wapen), dihukum dengan hukuman penjara selama-lamanya sepuluh tahun."

Unjuk rasa atau demonstrasi ini biasanya dilakukan untuk mendukung atau menolak suatu kebijakan yang dikeluarkan oleh pemerintah maupun swasta, menurut Pasal 1 angka 3 pada Undang-undang No. 9 tahun 1998 tentang Kemerdekaan Menyampaikan Pendapat di Muka Umum, disebutkan bahwa pengertian unjuk rasa adalah "kegiatan yang dilakukan oleh seseorang atau lebih untuk mengeluarkan pikiran dengan lisan, tulisan dan sebagainya secara demonstratif di muka umum. Dalam kalimat yang dimaksud dengan dimuka umum dalm Pasal 1 angka 2 Undangundang No. 9 tahun 1998 adalah dihadapan orang banyak, atau orang lain termasuk juga tempat yang dapat didatangi atau dilihat setiap orang.

Menurut Pasal 183 KUHAP yang menyatakan bahwa: "Hakim tidak boleh menjatuhkan pidana kepada seseorang, kecuali bila dengan sekurang-kurangnya dua alat bukti yang sah ia memperoleh keyakinan bahwa suatu tindak pidana benar-benar terjadi dan bahwa terdakwalah yang bersalah melakukannya"

Pasal 184 KUHAP menyatakan bahwa alat bukti yang sah adalah: (a) Keterangan Saksi; (b) Keterangan Ahli; (c) Surat; (d) Petunjuk; (e) Keterangan Terdakwa.

Undang-undang kepolisian Negara Republik Indonesia Nomor 2 Tahun 2002 diatur mengenai tugas Polri. Tugas pokok Polri diatur dalam pasal 13 Undang-Undang Nomor 2 Tahun 2002 sebagaimana saya jelaskan dalam bab I.

Kegiatan pengamanan dalam pelaksanaan penyampaian pendapat dimuka umum mengacu pada Peraturan Kapolri Nomor 7 Tahun 2012 tentang Tata cara penyelenggaraan pelayanan, pengaman, dan penanganan perkara penyampaian pendapat di muka umum, dimana menurut Pasal 18 huruf a bahwa: Penyelenggaraan pengamanan bertujuan untuk: 1) memberikan perlindungan keamanan terhadap peserta penyampaiaan pendapat di muka umum; 2) menjaga kebebasan penyampaian pennyampaian pendapat dari intervensi pihak lain; 3) menjaga keamanan dan ketertiban umum.

\section{Penegakan hukum terhadap tindak pidana tanpa hak menguasai senjata tajam dalam aksi unjuk rasa penolakan RUU KUHP di Pengadilan Negeri Medan}

Para preman membawa senjata tajam untuk kepentingan jahat, yaitu untuk melakukan pemerasan kepada para pedagang di pasar. Ada juga preman membawa senjata tajam untuk keperluan pengancaman kepada para pemilik toko, tujuannya juga untuk mendapatkan uang preman. Hal ini tentu telah menjelaskan bahwa tujuan membawa senjata tajam adalah untuk pekerjaan jahat (Kansil, 2012). 
Pelaku yang juga sering membawa senjata tajam adalah anggota geng motor, terutama anggota geng yang sering terlibat dalam tindak criminal. Tetapi keberadaan mereka sulit untuk diketahui karena terlindung di tengah-tengah massa geng yang biasanya berjumlah banyak.

Sering juga diketahui orang-orang membawa senjata tajam dalam aksi demonstrasi. Kejadian tersebut tidak jarang ditemukan yang kemungkinan disebabkan pelaku merasa tidak nyaman jika berada di tengah massa yang emosinya bisa meledak.

Peserta unjuk rasa juga sering diketahui membawa senjata tajam ke kerumunan massa, walaupun tidak dinampakkan, padahal senjata tajam tersebut tidak memiliki hubungan dengan tuntutan para pendemo. Biasanya pembawa senjata tajam tertangkap setelah aksi demonstrasi berlangsung rusuh.

Kesadaran masyarakat untuk tidak membawa atau memiliki senjata tajam kecuali untuk kepentingan pekerjaan masih tergolong rendah, sehingga kasus-kasus senjata tajam masih banyak terjadi (Reksodiputro, 2012). Untuk mengatasi masalah tersebut maka diperlukan penegakan hukum yang benar-benar dapat membuat para pelaku tidak mengulangi perbuatannya, serta menjadi contoh bagi pihak lain yang berniat membawa senjata tajam ke tempat umum atau ke dalam keramaian.

Ancaman pidana bagi pelaku pembawa senjata tajam adalah sangat berat, yaitu mencapai 10 tahun penjara. Tetapi tingginya ancaman pidana tersebut tidak berhasil mengendalikan pelaku pembawa senjata tajam, karena ternyata masih banyak ditemukan kasus yang membawa senjata tajam ke tempat umum dan ke dalam keramaian. Hal tersebut disebabkan masih lemahnya penegakan hukum terhadap pembawa senjata tajam, baik pada tingkat penyidikan, penuntutan, maupun putusan yang ditetapkan oleh majelis hakim.

\section{Kebijakan pidana terhadap tindak pidana tanpa hak menguasai senjata tajam}

Kebijakan penal merupakan bentuk penanggulangan kejahatan yang menitikberatkan pada pada tindakan represif setelah terjadinya suatu tindak pidana. Tindakan dilakukan terhadap pelaku pembawa senjata tajam berupa proses hukum, yaitu dengan melakukan pemeriksaan terhadap terdakwa di persidangan. Salah satu perkara dengan kebijakan penal yang dilakukan terhadap pelaku pembawa senjata tajam adalah atas nama terdakwa RUSLAN ABDUL GANI dalam putusan perkara No. 3437/Pid.Sus/2019/PN.Mdn yang mana pada saat itu sedang terjadinya unjuk rasa mahasiswa di sekitar Kantor DPRD Medan, yang kemudian dinyatakan bersalah membawa senjata tajam oleh Pengadilan Negeri Medan.

Tersangka Ruslan Abdul Gani telah dihadapkan ke Majelis Hakim Pengadilan Negeri Medan karena tanpa hak menguasai atau membawa atau mempunyai dalam miliknya atau menyimpan atau menyembunyikan atau mempergunakan, sesuatu senjata penikam atau senjata penusuk. Jaksa penuntut hukum menuntut agar majelis hakim menyatakan terdakwa Ruslan Abdul Gani terbukti secara sah dan meyakinkan bersalah melakukan tindak pidana "tanpa hak menguasai atau membawa atau mempunyai dalam miliknya atau menyimpan atau menyembunyikan atau mempergunakan sesuatu senjata penikam atau senjata penusuk", sebagaimana diatur dan diancam pidana melanggar Pasal 2 ayat (1) Undang-Undang Darurat No. 12 tahun 1951, dan oleh karena itu menjatuhkan pidana terhadap terdakwa dengan selama 10 (sepuluh) bulan dikurangi selama terdakwa dalam tahanan sementara dengan perintah agar terdakwa tetap ditahan.

Menurut pendapat penulis bahwa putusan hakim menyatakan terdakwa bersalah melakukan tindak pidana tanpa hak menguasai atau membawa atau mempunyai dalam miliknya atau menyimpan atau menyembunyikan atau mempergunakan sesuatu senjata penikam atau senjata penusuk, sudah tepat. Hal ini karena senjata tajam tersebut ditemukan saksi di dalam tas terdakwa.

Tetapi penulis kurang setuju terhadap putusan pidana yang dijatuhkan majelis hakim, yaitu 10 bulan. Menurut penulis bahwa perbuatan terdakwa seharusnya dipidana dengan penjara yang lebih berat. Majelis hakim seharusnya mempertimbangkan bahwa senjata tajam tersebut hendak di bawah terdakwa ke arah kerumunan massa dan bergabung dengan massa pengunjuk rasa yang sedang terjadi di sekitar Kantor DPRD (Pohan \& Hidayani, 2020). Orang yang membawa senjata tajam dalam berunjuk rasa lebih cenderung mempunyai keberanian yang tinggi untuk bertindak 1. http://mahesainstitute.web.id/ojs2/index.php/jehss $\circlearrowleft$ mahesainstitut@gmail.com 1078

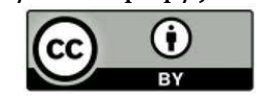


karena merasa ada senjata untuk melindungi dirinya, sehingga sangat berbahaya jika dibawa ke dalam kerumunan massa. Demikian juga jika senjata tajam nampak di kerumunan massa ada kemungkinan senjata tajam akan menimbulkan ketakutan, yang dapat menyebabkan massa menjadi tidak stabil karena takut, yang kemudian dapat memicu terjadinya kerusuhan dalam aksi unjuk rasa (Zulyadi \& Syahputra, 2020).

Kebijakan non penal adalah menangani dan menghapuskan faktor-faktor kondusif yang menyebabkan terjadinya suatu tindak pidana. Menurut pandangan politik kriminal bahwa kebijakan non merupakan kebijakan penanggulangan kejahatan yang paling strategis, karena bersifat pencegahan sebelum terjadinya tindak pidana. Upaya-upaya non penal menduduki posisi kunci dan strategis dari keseluruhan upaya kebijakan penanggulangan kriminal. Oleh karena itu dalam penelitian ini penulis menguraikan mengenai kebijakan non penal dalam penegakan hukum tindak pidana tanpa hak menguasai senjata tajam dalam aksi unjuk rasa. Kebijakan non penal yang dilakukan adalah penyuluhan. Penyuluhan salah satu bentuk upaya aparat kepolisian untuk mencegah terjadinya tindak pidana penyalahgunaan senjata tajam dikalangan masyarakat yaitu dengan mengadakan penyuluhan tentang dampak dan bahaya yang ditimbulkan oleh penyalahgunaan senjata tajam. Bentuk penyuluhan yang dilakukan dengan terjun secara langsung kepada masyarakat dengan cara persuasif.

Razia Salah satu upaya kepolisian untuk mengatasi masalah penyalahgunaan senjata tajam adalah melalui kegiatan razia. Razia merupakan penangkapan beramai-ramai atau penggerebekan penjahat yang berbahaya bagi keamanan (Zulyadi, 2020). Tindakan ini bertujuan untuk mengamankan masyarakat yang kedapatan membawa senjata tajam.

Partisipasi dimaksudkan bagaimana keikutsertaan masyarakat dalam pengambilan keputusan baik langsung maupun tidak langsung melalui lembaga perwakilan yang sah berdasarkan prinsip demokrasi yakni kebebasan berkumpul dan mengungkapkan pendapat secara konstruktif untuk mendorong partisipasi masyarakat dalam seluruh aspek pembanguan, termasuk dalam sektor-sektor sosial lainnya, maka regulasi birokrasi harus diminimalisir (Ramadhan, Dkk, 2020).

\section{SIMPULAN}

Aturan hukum mengenai penegakan hukum terhadap tindak pidana tanpa hak menguasai senjata tajam dalam aksi unjuk rasa diatur dalam Undang-Undang Darurat Nomor 12 Tahun 1951 pada Pasal 2 ayat (1), Undang-undang No. 9 Tahun 1998 tentang Kemerdekaan Menyampaikan Pendapat di Muka Umum pada Pasal 16, Perkapolri No. 7 tahun 2012 tentang Tata Cara Penyelenggaraan Pelayanan, Pengamanan, dan Penanganan Perkara Penyampaian Pendapat di Muka Umum pada Pasal 8 huruf j. Penegakan hukum terhadap tindak pidana tanpa hak menguasai senjata tajam dalam aksi unjuk rasa penolakan RUU KUHP di Pengadilan Negeri Medan dilakukan melalui penyidikan: khusus untuk pembawa senjata tajam yang nyata-nyata akan digunakan dalam tindak pidana, maka kepolisian akan melakukan penindakan secara tegas. Penuntutan: tindak pidana senjata tajam bukanlah perkara yang dianggap luar biasa, karena kondisi negara tidak dalam keadaan darurat. Putusan hakim: hakim yang mengadili tindak pidana senjata tajam menetapkan vonis lebih mempertimbangkan jaksa penuntut umum. Tuntutan jaksa yang tergolong rendah terhadap tindak pidana senjata tajam telah turut menyebabkan lemahnya penegakan hukum pelaku pembawa senjata tajam dan senjata penikam. Kebijakan hukum pidana terhadap orang yang membawa senjata tajam di Kota Medan terdiri dari kebijakan penal dilakukan dengan memproses pelaku secara hukum yang dilanjutkan dengan melakukan pemeriksaan terhadap terdakwa di persidangan. Kebijakan non penal sebagai tindakan pencegahan tindak pidana tanpa hak menguasai senjata tajam adalah penyuluhan, razia dan partisipasi masyarakat. 


\section{DAFTAR PUSTAKA}

Ediwarman. (2016). Monograf Metode Penelitian Hukum (Panduan Penulisan Skripsi, Tesis, dan Disertasi). Medan: Genta Publishing.

Kansil, C. S. T. (2012). Pengantar Ilmu Hukum dan Tata Hukum Indonesia. Jakarta: Balai Pustaka.

Koeswadji. (2013). Perkembangan Macam-macam Pidana dalam Rangka Pembangunan Hukum Pidana. Bandung: Citra Aditya Bhakti.

Moleong, L. J. (2015). Metodologi Penelitian Kualitatif. Bandung: Remaja Rosdakarya.

Muladi., \& Nawawi, B. (2012). Teori dan Kebijakan Pidana. Bandung: Alumni.

Pohan, M.N., \& Hidayani, S. (2020). Tinjauan Hukum pada Tindak Pidana Melakukan Persetubuhan Terhadap Anak Dari Undang-Undang Nomor 35 Tahun 2014. Journal of Education, Humaniora and Social Sciences (JEHSS), 3(2), 377-385. doi:https://doi.org/10.34007/jehss.v3i2.313

Rahardjo, S. (2015). Permasalahan Hukum di Indonesia. Bandung: Alumni.

Ramadhan, M., Marlina, M., \& Isnaini, I. (2020). Pencegahan Terjadinya Tindak Pidana Nakotika pada Anak di Kelurahan Bantan Timur. Journal of Education, Humaniora and Social Sciences (JEHSS), 2 (3), 540553. doi:https://doi.org/10.34007/jehss.v2i3.115

Reksodiputro, M. (2012). Sistem Peradilan Pidana (Peran Penegak Hukum Melawan Kejahatan), Pusat Pelayanan Keadilan dan Pengabdian Hukum. Jakarta: Universitas Indonesia.

Soekanto, S. (2012). Pengantar Penelitian Hukum. Jakarta: Universitas Indonesia Press.

Zulyadi, R. (2020). Police's Role to Prevent Criminal Act of Rape-Murder (Study Case of Police Labuhan Ruku Talawi Sub-District, Batubara District, North Sumatera). SIASAT, 5(2), 39-46

Zulyadi, R., \& Syahputra, M.Y.A. (2020). Perlindungan HUkum terhadap Anak Sebagai Korban Perdagangan Manusia, Pustaka Prima, Medan

Peraturan Perundang-undangan:

Undang-undang No. 2 Tahun 2002 Tentang Kepolisian Negara Republik Indonesia.

Kitab Undang-Undang Hukum Pidana (KUHP).

Kitab Undang-Undang Hukum Acara Pidana (KUHAP).

Undang-undang No. 9 Tahun 1998 Tentang Kemerdekaan Menyampaikan Pendapat di Muka Umum.

Perkapolri No. 7 tahun 2012 tentang Tata Cara Penyelenggaraan Pelayanan, Pengamanan, dan Penanganan Perkara Penyampaian Pendapat di Muka Umum. 